\title{
CORPORATE GOVERNANCE STRUCTURE AND FIRM PERFORMANCE IN SMALL AND MEDIUM-SIZED ENTERPRISES (SMES) IN SRI LANKA: A PATH TO ACCESS THE CREDIT
}

\author{
Raisal Ismail \\ Department of Management, \\ South Eastern University of Sri Lanka, University Park, Oluvil, Sri Lanka. \\ Email: ismarais@seu.ac.lk
}

\section{Arun Kumar Tarofder}

Faculty of Business Management and Professional Studies, Management and Science University, Malaysia

\begin{abstract}
The purpose of this study is to analyse how the adoption of corporate governance structures affects the performance of SMEs in Sri Lanka. For this purpose, we examine the effect of board composition, board size, board and staff skill levels, board leadership (duality), and family ownership on firm performance. To obtain unbiased estimators for the effects of the independent variables, contextual factors such as firm age, firm size, and debt ratio are included as controls for corporate governance structure and performance relationships.

Panel regression analysis is used to estimate the relationship between corporate governance and performance. The results show that all measures including board composition, board size, board and staff skill levels, board leadership (duality), and family ownership have significantly positive impacts on profitability. Corporate governance can greatly assist the SME sector by infusing better management practices. It is also clear that corporate governance structures influence the performance of SMEs in Sri Lanka. The finding also shows the implications of SMEs gaining access to finance as a result of adopting a good governance system.
\end{abstract}

Keywords: Corporate governance, SMEs, Firm performance, Access to finance, Panel regression, Board structure

\section{Background}

Corporate governance has attracted much almost led to a collapse of the financial system attention in the last decade since the Asian followedbythedeep global recession emphasise financial crisis and the outbreak of US corporate the importance of corporate governance (Lang scandals, especially in the light of recent Global financial crises, which arose partly as a result of non-optimal corporate governance practices among several organisations across the globe. The catastrophic losses of financial firms which \& Jagtiani, 2010).

Many researchers have established a strong link between good corporate governance and sustainable business and economic growth. 
Claessens et al. (2002) say that better corporate governance frameworks benefit firms through greater access to financing, lower cost of capital, better performance and more favourable treatment of all stakeholders. Corporate governance brings new strategic outlooks through external independent directors; it enhances firms' corporate entrepreneurship and competitiveness (Abor \& Adjasi, 2007).

One of the key problems that have bedevilled the SMEs globally has been accessing to credit. The credit crunch and its accompanying dwindling of confidence resulting from the global financial crisis have shrunk bank lending, resulting in limited or no access to working capital for the SMEs. This inability to directly access the capital markets puts the SMEs at a competitive disadvantage relative to larger firms.

Small and Medium-sized Enterprises (SMEs) continue to be central to the economic development of Sri Lanka. Pandula (2015) stated that around 80 percent of the businesses in Sri Lanka are considered to be SMEs. Additionally, SMEs contribute 50 percent to the Gross Domestic Production of the country and employ 26 percent of the labour force and have a value addition of 17 percent (Institute of Policy Studies \& Oxfam International, 2014). However, most financial providers consider that financing SMEs is a risky business that generates high transaction costs and/ or low returns on investment (i.e. declining performance), and therefore hesitate to grant loans to potential clients in this sector. In fact, the World Bank's 2011 Investment Climate
Assessment Survey in Sri Lanka, reveals that around 35 percent of Sri Lankan small firms can access a loan or a line of credit and around 14 percent of those who applied were denied financing. Therefore developing solutions to this major concern should be a top priority for most of the SMEs in Sri Lanka.

Lack of managerial competencies and proper governance systems in the SME sector have been identified to swamp efforts at attracting such finance and thus are said to be the main barriers to SME development (Gockel \& Akoena, 2002). It is necessary then for proper management of the SME sector to ensure enhanced performance, given that this would have major implications for financing opportunities for the sector. Therefore, we believe that the adoption of good governance practices among SMEs may assist them to come out from the present chaos that they encounter in Sri Lanka.

\section{Review of Literature}

\section{Board Composition}

Boards of directors are essential elements to most definitions of corporate governance. They bring out the formal link between owners and their managers responsible for the day-today operations of the SME. Most researchers agree that corporate boards are important to the accountability of corporations and the way corporations comply with modern ethical and economic standards.

Thus, the significance of the board for SMEs cannot be over emphasised. However most SMEs, are closely held and owner-managed 
and the owners usually do have direct and more insights into internal processes of the firm. Consequently, for most SMEs boards exist on paper only, the boards control function is non-existent. On the other hand, there are also instances of SMEs having active boards with outside members, where the board is used as an instrument of strategy development (Fiengener et al. 2005). The outside members usually view the tasks of the board as being clearly different and complementary to that of management, whereas insiders may view the board work as an extension of their managerial duties. The outside board members are not tied to the dayto-day activities of the SME and as a result, they are likely to think more freely regarding the strategic alternatives open to the SME (Forbes \& Milliken, 1999).

The debate on what should be the preferred board composition appear to tilt more favourably towards the board with more outside directors than inside. John \& Senbet (1998) argue that boards of directors are seen to be more independent as the proportion of their non-executive directors increases. Rosenstein \& Wyatt, (1990) and Brickley et al. (1994) supported that the market reward firms for appointing non-executive directors. In other words, an SME with more outside directors will be perceived more favourably by the market and financial institutions than SMEs with more inside directors.

\section{Board Size}

SMEs by their nature tend to have very smaller board sizes. Jensen (1993) argues that large boards are less effective and are easier for the
CEO to control. When a board gets too big, it becomes difficult to coordinate and often creates problems. Smaller boards also reduce the possibility of free riding by and increase the accountability of individual directors. These arguments albeit there is still a strong case for SMEs to increase their board membership beyond the usual two to four. Transitioning from owner-manager to a company with a wide board is one of the most important transitions that an SME can undergo. This team approach permits clearer development and definition of the choices facing the business. Some researchers found a strong link between widened boards improved performance of SMEs (Wynarczyk et al., 1993). The result is even more impressive where there are more non-executive directors (Cowen \& Osborne, 1993). Thus, SMEs with a larger board is more likely to have a better corporate governance environment than the ones with smaller ones.

\section{Board and staff skill levels}

Lybaert (1998) argues that better performance is due to the proven positive relation of higher levels of education among entrepreneurs and their willingness to use external information, develop networks, make use of consultants or develop more detailed accounting and monitoring. However, there is contrary evidence about the level of training among SMEs owners and managers. Lawrie (1998) demonstrates that gaps in management expertise are less of a recognised barrier to SME development than the availability of specialist staff skills, mainly IT and languages. Therefore, although higher-level management qualifications may be useful to SMEs, there is still some doubt as to their relevance. Powell (1991) maintains 
that there may even be a negative effect on firm performance as a result of the occupational and professional affiliations of highly qualified managers which may encourage increased agency behaviour.

\section{Board leadership (Duality)}

Another imperative aspect of dealing with when analysing the governance structure is the coincidence in the same person of the figures of the chairman and chief executive. Prior literature acknowledges that the type of board leadership and a role of the Chief Executive Officer (CEO) can have an influence on firm performance. A substantial body of research has focused on the association between firm performance and CEO leadership. The empirical evidence is no conclusive on CEO duality, and several studies even find no significant effect on firm performance.

The Cadbury report (1992) state that the role of chairman should be separated from the role of CEO; if the two roles are combined in one person, it represents a considerable concentration of power within the decisionmaking process.

It has been noted that the system where the CEO also acts as board chairman leads to leadership facing the conflict of interest and agency problems (Brickley et al., 1997) thus giving preference for the system where the CEO's role is separated from that of the board chairman. Yermack (1996) argues that firms are more valuable when the CEO and board chair positions are separate. Relating CEO duality more specifically to firm performance, researchers, however, found mixed evidence.
Daily \& Dalton (1992) found no relationship between CEO duality and performance in entrepreneurial firms. Brickley et al. (1997) showed that CEO duality is not associated with inferior performance. Rechner \& Dalton (1991) also reported that companies with CEO duality have stronger financial performance relative to other companies.

\section{Family ownership}

It is often argued that the benefit of founding family leadership of firms is that family traits, such as trust, altruism and paternalism can create an atmosphere of love and commitment towards the business (James, 1999) and therefore curtail agency costs. Previous studies by James (1999) showed that founding family businesses provide special kind of corporate governance that offers lower agency costs and better performance. Other studies, however, indicated that entrepreneurs and managers of founding family firms are more likely to engage in managerial entrenchment to the detriment of the firm, resulting in weaker performance (Thomsen \& Pedersen, 2000).

\section{Empirical research: method, data and analysis}

This study is subject to certain delimitation in order to reach a representative set of the population. First, the restrictions concerning the legal form of companies were imposed: we focused on limited companies and private limited companies as they have a legal obligation to establish boards of directors. Second we excluded the companies affected by special situations such as insolvency, windingup, or liquidation. Third, we eliminated listed 
companies. Finally, we studied only firms that had between 20 and 149 employees'. Task Force (2002). With this condition, the sample under study comprised 120 non-listed SMEs were selected for this study.

The data used in the empirical analysis was obtained from the SMEs in both the industrial and services sectors during a six-year period, 2009-2014. Information on governance and ownership issues was also obtained through interviews with the management of the firms.

Profitability is used as a measure of performance and is defined in terms of return on assets (i.e. profit before interest and taxes divided by total assets). The independent variables include board composition, and board Size, board and staff skill levels, board leadership (duality), and family ownership.

The measure for Board composition is the proportion of non-executive directors. Board size is the number of board members. Board skill is the number of board members with the degree or professional qualification. The measure for CEO duality is a binary that equals one if the CEO is also the chairman of the board. Family ownership is a dummy variable that equals one if the firm is family owned. Family ownership is defined by a majority ownership (more than 50 percent) held by a family or a family group, while they are family-ownedand-managed if owners are also managers for the daily operation of the firms. In addition, we control for firm size, firm age, and debt ratio. Size is defined as the log of total assets. Age is the number of years between the observation year and the firm's year of incorporation. The debt ratio is the ratio of total debt to total capital.

This study employs a panel regression model which involves the pooling of observations on a cross-section of units over several time periods and provides results that are simply not detectable in pure cross-sections or pure timeseries studies. The panel regression equation differs from a regular time-series or crosssection regression by the double subscript attached to each variable. The general form of the panel data model can be specified more compactly as:

$\mathrm{Y}_{\mathrm{it}}=\alpha_{\mathrm{it}}+\beta \mathrm{X}_{\mathrm{it}}+{ }^{\delta} \mathrm{w}_{\mathrm{it}}+\mathrm{kc}_{\mathrm{it}}+\mu_{\mathrm{it}}$

Where $Y_{\text {it }}$,represents the firm's performance, $\mathrm{X}_{\mathrm{it}}$ is a vector of board factors, $\mathrm{W}_{\mathrm{it}}$ is a vector for the ownership variables, $\mathrm{C}_{\mathrm{it}}$ includes the set of control variables, $\alpha_{\text {it }}$ is taken to be constant over time " $t$ " and specific to the individual cross-sectional unit " $i$ " and $\mu_{i t}$ is the error term in the model. Since performance is given as a function of both board and ownership characteristics, our model can be restated as:

Perf $=\alpha+\beta($ board $)+{ }^{\delta}($ ownership $)+\mathrm{k}($ constant factors $)+\mu$

Our method of pooling cross-sectional and time series data is susceptible to heteroscedasticity. We, therefore, checked for this problem using White heteroscedastic-consistent standard errors and covariance. To ensure the robustness of the model, we also include three control variables, size, age, and debt ratio to minimise specification bias. These are standard variables in performance models. 


\section{Empirical results}

\section{Descriptive summary statistics}

The descriptive statistics for all the variables are presented in Table: 01 . The average profitability is 10 , meaning the average return on assets stands at approximately 10 percent. Average board size for this sample of SMEs is about 04 . The average board composition is given as 46 percent. The mean board skill
Least Squares (GLS) White heteroscedasticconsistent with standard errors panel regression corrected are presented in Table 02 . The results from the regression model denote that the independent variables explain the performance determination of the firms at 38.1 percent. The F-statistics prove the validity of the estimated models.

Table: 01

Descriptive statistics of Sample firms; means and standard deviation value for variable measure

\begin{tabular}{|c|c|c|}
\hline & Mean & SD \\
\hline $\mathrm{ROA}(\%)$ & 10 & 16 \\
\hline Board composition $(\%)$ & 46 & 29 \\
\hline Board size & 3.69 & 1.49 \\
\hline Board and staff skills level & 2.12 & 1.62 \\
\hline Board leadership (duality) & 92 & 31 \\
\hline Family ownership (\%) & 73 & 37 \\
\hline Size of the firm & 43493.16 & 110363.2 \\
\hline Age of the firm & 11.61 & 8.85 \\
\hline Debt ratio (\%) & 38 & 31 \\
\hline
\end{tabular}

is 02 . This means, on the average there are 02 board members with the degree or professional qualification. The $92 \%$ of the SMEs have the CEO also actin as chairperson on the board. The results also indicate that our sample includes 73 percent family-owned businesses. The average value of the firms' assets is 43493.16 Sri Lankan rupees and an average number of years the firms have been in business is 12 years. The average debt ratio is also shown as 38 percent.

\section{Regression results}

Regression analysis is used to investigate the relationship between measures of corporate governance, ownership structure and performance. The results of the Generalised
The results of this study reveal that board composition has a significantly positive relationship with firm profitability. In this regard, the importance of non-executive directors in terms of their external experience regarding sound financial and legal basis is revealed in the positive relationship the variable has with firm performance. Thus, as the ratio of board composition (number of outside board members/total board members) rises firms tend to perform better. This is because external board members may have knowledge and information on financing sources. Increasing access to finance thus has the tendency of boosting the firm's bottom line. 
Table: 02

Results from the Regression model

\begin{tabular}{lllc}
\hline Variable & Coefficient & t-statistic & Prob. \\
\hline Constant & & & \\
Board composition & 0.127 & 6.515 & 0.0000 \\
Board size & 0.015 & 2.325 & 0.0162 \\
Board skill & 0.007 & 4.301 & 0.0000 \\
Board Leadership (duality) & 0.013 & 0.676 & 0.0001 \\
Family ownership & 0.010 & 3.816 & 0.0001 \\
Size of the firm & -.013 & 2.859 & 0.0045 \\
Age of the firm & 0.001 & -6.754 & 0.0000 \\
Debt ratio & -.107 & 4.102 & 0.0000 \\
\hline
\end{tabular}

R-squared 0.381, F-statistic 24.29

The statistically significant and positive association between board size and performance suggests that relatively larger boards perform better compared to very small boards because larger boards have a range of expertise to help make better decisions. In the case of SMEs, encouraging team development through a extend board has been argued to be an important step in improved corporate governance and this leads to improved firm performance. In this study of SMEs, the mean board size was only approximately four. The largest board was composed of eight board members and the minimum board size was also made up of two members. In Sri Lanka, the companies' code stipulates a minimum number of two board members for registering a company. This may explain why some SMEs would only have two board members. Clearly, the results of this study have shown that SMEs with a board size of four would demonstrate better performance than those with only two board members.
The level of training among directors and managers could have a strong influence on the performance of the firm. The results of this study show a significantly positive relationship between performance and skill level of the management. This is indicative of the fact that SMEs with highly qualified management team tend to exhibit high profitability. This stresses the importance of managerial skills and business experience as means of promoting firm performance.

The results of this study indicate a statistically significant and positive relationship between board leadership (CEO) duality and firm performance. This suggests that in SMEs where an individual combines the roles of both the CEO and board chairman rather demonstrate better performance than those with two individuals performing such roles. In this study, a high percentage (92 percent) of the firms has the $\mathrm{CEO}$ also acting as the chairman 
of the board. This is particularly not surprising in the case of SMEs which tend to exhibit control aversion.

Similarly, the significantly positive interaction between family ownership and profitability signals the fact that family ownership creates an atmosphere of love and commitment necessary for better performance. Family-owned firms are more likely to experience cooperation, unity, commitment, and lesser conflicts, thus resulting in lower agency costs. Such an environment is more likely to be conducive to enhanced performance. This appears to be consistent with the findings of Mishra et al. (2001) who argue that founding family businesses provide special kind of corporate governance that offers lower agency costs and better performance.

\section{Conclusion}

The significance of corporate governance has been addressed mostly within the context of large, publicly listed firms. However, less attention has been paid to the area with respect to SMEs. This paper investigated the effects of corporate governance and the performance of SMEs in Sri Lanka. The results of this study show that board composition, board size, board and staff skill level, CEO duality, and family ownership have significantly positive impacts on profitability.

The results of this study generally suggest that the adoption of corporate governance structures has some important implications for Sri Lankan SMEs. Corporate governance can greatly assist the SME sector by infusing better management practices, stronger internal auditing, greater opportunities for growth and new strategic outlook through non-executive directors. Good governance mechanisms among SMEs are likely to result in boards exerting much-needed pressure for improved performance by ensuring that the interests of the firms are served. One major implication of a well-functioning corporate governance system is easier access to funding from investors and financial institutions. SMEs have generally been noted to encounter greater difficulty in gaining access to financing due to problems of, high transaction cost, information irregularities and lower return on investment. Ensuring proper accounting practices, internal control systems, adequate information disclosure is likely to increase the confidence of investors in the firm, reduce the problems associated with information irregularities and make the SME less risky to invest in.

Small firms are particularly weak and often ignorant of sources of finance open to their firms. Most of the time, they do not know how to position themselves correctly to be viewed favourably by finance providers. The non-executive board members may have good knowledge or useful information on financing facilities. Thus, the existence of such directors could lead to better management decisions and help SMEs to attract better resources.

\section{Reference}

Abor, J., \& Adjasi,C.K.D. (2007). "Corporate governance and the small and medium enterprises sector: theory and implications", International journal of business in society, 7 (2), $111-122$ 
Brickley, J. A., Coles, J. L., \& Jarrell, G. (1997). Leadership structure: Separating the CEO and chairman of the board. Journal of Corporate Finance, 3, 189-220.

Cadbury Report on Financial Aspects of Corporate Governance in the United Kingdom (1992) Chicago, IL, 183-203.

Claessens, S., Fan, J. P. H. (2002). Corporate governance in Asia: A survey, International Review of Finance, 3 (2), 71-103.

Cowen, S.S. \& Osborne, R.L. (1993), Board of directors as strategy, Journal of General Management, 19, 1-13.

Daily,C.M., Dalton,D.R.(1992). The relationship between governance structure and corporate performance in entrepreneurial firms, Journal of Business Venturing, 7, (5), 375-386,

Fiegener, M. K., Brown, B. M., Dreux, D. R., \& Dennis, W. J. (2000). The adoption of outside boards by small private US firms. Entrepreneurship and Regional Development, 12, 291-309.

Forbes, D. P., \& Milliken, F. (1999). Cognition and corporate governance: Understanding board of directors as strategic decision: Making groups. Academy of Management Review, 3, 489-505.

Gockel, A.G. \& Akoena, S.K. (2002). Financial intermediation for the poor: credit demand by micro, small and medium scale enterprises in Ghana: a further assignment for financial sector policy? IFLIP Research Paper 02-6, International Labour Organisation, Geneva.
Institute of Policy Studies \& Oxfam International, (2014).

Female entrepreneurship and the role of business development services in promoting Small and medium women entrepreneurs in Sri Lanka. Colombo

James, H.S. Jr (1999), Owner as manager, extended horizons and the family firm, International Journal of the Economics of Business, 6 (1), 41-55.

Jensen, M. C. (1993). The modern industrial revolution, exit, and the failure of internal control systems. Journal of Finance, 48, 831-880.

John, K., \& Senbet, L. W. (1998). Corporate governance and board effectiveness. Journal of Banking and Finance, 22, 371403.

Lang,WW., \& Jagtiani,J.A. (2010). The mortgage and financial crises: The role of credit risk management and corporate governance, Atlantic Economic Journal, Volume 38(2), 123

Lawrie, A. (1998). Small Firms Survey: Skills, British Chambers of Commerce, London

Liang, N., \& Li, J. (1999). Board structure and firm performance: New evidence from China's private firms. Academy of Management Annual Conference, 7-10.

Lybaert, N. (1998). The information use in an SME: Its importance and some elements of influence, Small Business Economics, 10, 171-91. 
Mishra, C., Randøy, T. \& Jenssen, J.I. (2001). The effect of founding family influence on firm value and corporate governance: A study of Norwegian firms, Journal of International Financial Management and Accounting, 12 (3), 235-59.

Pandula G, (2015). Bank finance for small and medium-sized enterprises in Sri Lanka: issues and policy reforms, Studies in Business and Economics. 10, (2), 32-43.

Powell, W.W. (1991). Expanding the scope of institutional analysis, University of Chicago Press,

Rechner, P.L. \& Dalton, D.R. (1991). CEO duality and organisational performance: A longitudinal analysis, Strategic Management Journal, 12 (2), 155-60.

Rosenstein, S. \& Wyatt, J. (1990), Outside directors, board effectiveness and shareholders' wealth', Journal of Financial Economics, 26, 175-91.
Task Force for small and medium enterprise sector development in Sri Lanka, (2002). National strategy for small and medium enterprise sector development in Sri Lanka, SME White paper, Colombo.

Thomsen, S. \& Pedersen, T. (2000). Ownership structure and economic performance in the largest European companies, Strategic Management Journal, 21, 689-705.

Wynarczyk, P., Waston, R., Storey, D., Short, H. \& Keasey, K. (1993). The managerial labour market in Small to Medium-sized Enterprises, Routledge, London.

Yermack, D. (1996). Higher market valuation of companies with a small board of directors, Journal of Financial Economics, 40 (2), 185-211. 